\title{
The Acromion and its Different Forms
}

\author{
El Acromion y sus Diferentes Formas
}

*Collipal, E.; "Silva, H.; ** Ortega, L.; *Espinoza, E. \& ***Martínez C.

COLLIPAL, E.; SILVA, H.; ORTEGA, L.; ESPINOZA, E. \& MARTÍNEZ, C. The acromion and its different forms. Int. J. Morphol., 28(4):1189-1192, 2010.

SUMMARY: The morphology of the acromion, its relation to the coracoid process and the supraglenoid tubercle is important in the determination of the dimension of the subacromial space, considering that the variations of these structures can promote pathologies such as impingement syndrome of the subacromial space. There is little information on the different dimensions and forms of the acromion. We studied in 36 scapulae at the museum of the Anatomy Unit, Universidad de La Frontera, the following parameters: length, denseness, width, anterior projection, distance acromiocoracoid and acromion supraglenoid. According to this form, the type was qualified in acromion type I (plane) type II (curved) and type III (hooked). The averages of the variable length, anterior projection were statistically significant in the acromion of the right side. In relation to its classification $8 \%$ was type I, $50 \%$ type II, and $42 \%$ type III. The anatomically obtained information will allow health professionals to access new morphometric information regarding the acromion and use it as a base for future pathology investigation of the upper arm.

KEY WORDS: Acromion: Morphometry; Anatomy.

\section{INTRODUCTION}

In the description of the acromion a superior rough surface is considered to be in direct relation with the skin and concave lower surface that covers the shoulder joint, the thick and rough external border, a thin internal border in which an oval surface is traced, which major diameter is anterosuperior directed to articulate with the clavicle, an extreme anterior in which the acromiocoracoid ligament is inserted Testut \& Latarjet (1971).

The variation of the acromion form has been studied by different authors as Bigliani et al. (1986), who classified the acromion in type I plane, type II curved, acromion type III hooked acromion.

According to Ikemoto (2005), the possibility of having a type III acromion is greater as the subject's age increases, allowing for speculation that a hooked form of the acromion is a degenerative process.

Variation in the form of the acromion has been associated with pathologies such as subacromial impingement syndrome, defined as a painful process caused by the friction between the inferior surface of the anterior acromion, the coracoacromial ligament on the one hand, the subacromial bursa and the rotator cuff on the other. The form, size and above all the excessive anterior prominence of the acromion are the main factors involved in the origin of this injury, Neer (1972).

A study in 420 scapulae of cadavers performed by Nicholson et al. (1996), indicates that the primary morphology of the acromion does not change with age, and the distribution of the different types of acromion varies beginning at age fifty; there is a significant increase in the prevalence of spur formation beginning at age fifty.

Arenas et al. (2005) performed a retrospective form study of the clinical material of 87 cases of subacromial syndrome with rupture of the rotator cuff, conventional radiology supported that the form of type I acromion was of $4.7 \%$, type II $51.76 \%$ and type III $43.52 \%$. Epstein et al. (1993) indicate that acromion type III or hooked acromion

* Department of Basic Sciences, Faculty of Medicine, Universidad de La Frontera, Chile.

** Student Aides, Faculty of Medicine, Universidad de La Frontera, Chile.

**** Department of Education, Universidad de La Frontera, Chile. 
were viewed with a frequency of two times greater in patients with impingement syndrome of the rotators, in addition to the presence of this type of acromion in an MRI, could help identify those individuals at risk of developing impingement or rupture of the rotators.

The objective of the present study was to determine the morphology of the acromion with the aim of establishing different forms according to the Bigliani classification as well as to determine the different dimension in relation to the length, width, denseness anterior projection and relation with adjoining structures, such as supraglenoid tubercle and coracoid process.

\section{MATERIAL AND METHOD}

The material used in this investigation corresponded to 36 scapulae (16 right and 20 left) of adult subjects from the Museum of the Anatomy Unit, Faculty of Medicine, Universidad de La Frontera, Temuco, Chile. With a digital paquimeter and a metric precision tape the following measurements and observations of the acromion were obtained: length, width, denseness, anterior projection, distance between the acromion and coracoid process, between acromion and supraglenoid tubercle, additionally the shape of the surface of the inferior surface and lateral aspect of the acromion were observed in order to realize its classification. Each one of these measurements and observations were performed by two investigators, three times in separate times tabulating the average of said measurement. The $\mathrm{T}$ test was performed for non-parametric samples with the SPSS 13. program.

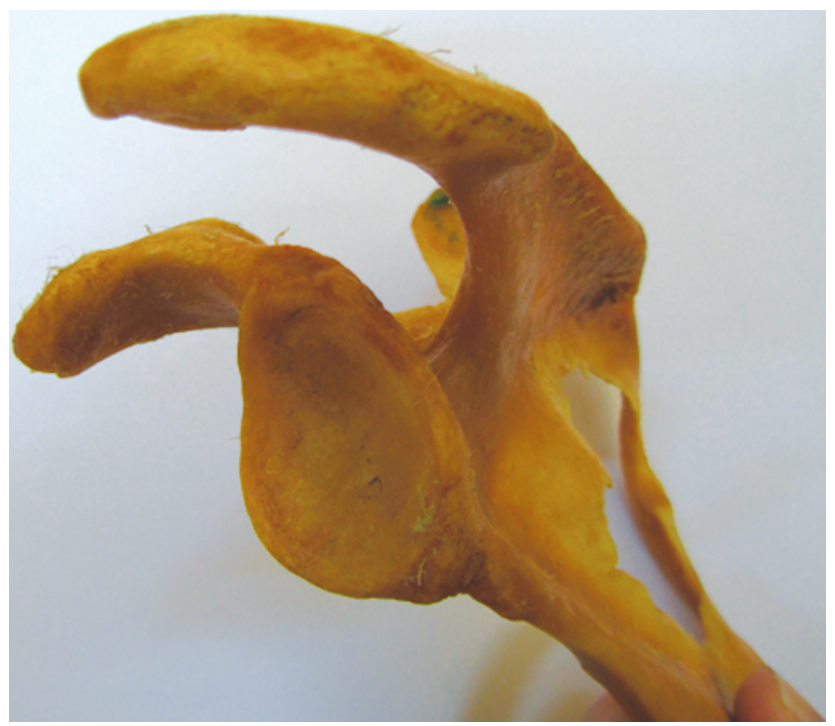

Fig. 1. Type 1 acromion according to Bigliani classification.

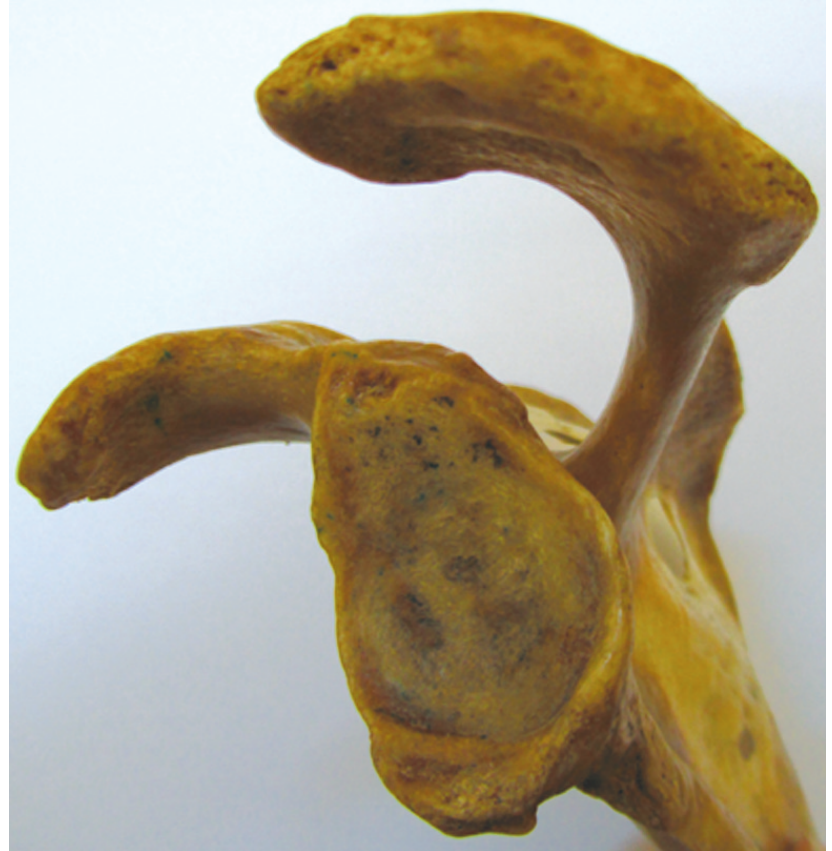

Fig. 2. Type 2 acromion according to Bigliani classification.

\section{RESULTS AND DISCUSSION}

The results of the shape of the acromion and its different dimensions demonstrate that in the scapulae studied, the acromion type I presented in $8 \%$, of type II in $50 \%$, and in type III in $42 \%$, indicating a greater presence of acromion type II in the population studied, according to studies performed by Getz et al. (1996); Shah et al. (2001); Natsis et al. (2007); Oda et al. (2000); Paraskevas et al. (2008), whose investigation was carried out in macerated scapulae through visual inspection, the classification method carried out through images, also indicate a greater percentage of this type of acromion, even in those cases where authors as Shippinger et al. (1997), Wang et al. (2000), in their research found a greater percentage of acromion type I and II.

In the morphometric evaluation of the acromion according to studies by Paraskevas et al., the average width was $22.3 \mathrm{~mm}$ (19-28(, denseness of 8.8mm (7-11), length $46.1 \mathrm{~mm}(38-55)$. In our study the width of the acromion was $24.5 \mathrm{~mm}$, denseness $8.5 \mathrm{~mm}$ and average length was $65.8 \mathrm{~mm}$. We could assume that the difference in relation to the length was because the measurement in our study was taken from the most anterior point of the apex acromion, to the base formed by the expansion of the spine scapulae.

The acromion morphology according to Epstein et al., appears to have a prediction value to determine the success of conservative medical treatment in some cases and 
Table I. Mean values in millimeters of right and left acromion in scapulae of the museum of adult individuals. Anatomy Unit, Universidad de La Frontera, Temuco, Chile.

\begin{tabular}{lcccc}
\hline & \multicolumn{2}{c}{ Right scapulae } & \multicolumn{2}{c}{ Left scapulae } \\
\hline & $\mathrm{X}(\mathrm{mm})$ & $\mathrm{DS}$ & $\mathrm{X}$ & $\mathrm{DS}$ \\
Length & 69.12 & 3.5 & 63.15 & 7.1 \\
Thickness & 8.73 & 0.8 & 8.42 & 1.0 \\
Width & 25.12 & 1.8 & 24.12 & 2.9 \\
Anterior projection & 46.84 & 3.3 & 41.73 & 5.9 \\
DistanceA-PC & 39.76 & 5.2 & 39.55 & 5.4 \\
Distance A-TS & 28.24 & 2.7 & 28.43 & 2.7 \\
\hline
\end{tabular}

Table II. T test applied to the variables studied in the acromion in scapulae of the museum of adult individuals. Anatomy Unit, Universidad de La Frontera, Temuco, Chile.

\begin{tabular}{lccc}
\hline \multicolumn{1}{c}{ Variables } & Right & Left & T Value \\
\hline Length & 69.12 & 63.15 & 0.004 \\
Width & 25.12 & 24.12 & 0.2 \\
Thickness & 8.73 & 8.42 & 0.3 \\
Projection & 46.84 & 41.73 & 0.003 \\
Acrocoracoides & 39.76 & 39.55 & 0.9 \\
Acromio supraglenoideo & 28.24 & 28.43 & 0.8 \\
\hline
\end{tabular}

the need for surgery in patients with joint impingement. Acromion of the hook type were observed with two times greater frequency in patients with rotator cuff impingement syndrome. rotator cuff (Natsis et al.).

The anatomy of the acromion and related structures in the shoulder joint is of importance and useful to successfully carry out interpretation of images and surgical procedures in pathologies associated with this joint.

Table III. Types of acromion and distribution in the literature.

\begin{tabular}{|c|c|c|c|c|}
\hline & Classification method & Type I, \% & Type II, \% & Type II, \% \\
\hline Bigliani et al. (1986) & Radiography & 18.6 & 42.0 & 38.6 \\
\hline Morrison et al. (1987) & Radiography & 18.0 & 41.0 & 41.0 \\
\hline Epstein et al. (1993) & MRI & 43.0 & 45.0 & 13.0 \\
\hline Toivonen et al. (1995) & Radiography / MRI & $5.4 / 14.3$ & $62.5 / 62.5$ & $32.1 / 23.2$ \\
\hline Getz et al (1996) & Visual Inspection & 22.8 & 68.5 & 8.6 \\
\hline Nicholson et al. (1996) & Radiography & 32.0 & 42.0 & 26.0 \\
\hline Schippinger et al. (1997) & MRI & 67.7 & 32.3 & 0.0 \\
\hline Wang et al. (1997) & Radiography & 40.8 & 44.9 & 14.3 \\
\hline MacGillivray et al. (1998) & M R I & 40.0 & 52.0 & 8.0 \\
\hline Oda et al. (2000) & Visual Inspection & 34.0 & 50.0 & 16.0 \\
\hline Wang et al. (2000) & Radiography / MRI & $6.0 / 6.0$ & $66.0 / 69.0$ & $28.0 / 25.8$ \\
\hline Shah et al. (2001) & Visual Inspection & 17.0 & 83.0 & 0.0 \\
\hline Speer et al. (2001) & Radiography & 11.5 & 84.5 & 4.0 \\
\hline Hirano et al. (2002) & MRI & 36.3 & 24.2 & 39.6 \\
\hline Worland et al. (2003) & Radiography & 7.6 & 50.0 & 42.4 \\
\hline Arenas et al. (2005) & Radiography & 4.7 & 51.7 & 43.5 \\
\hline Ikemoto et al.(2005) & Radiography & 29.1 & 50.5 & 20.4 \\
\hline Mayerhoefer et al. (2005) & MRI & 10.7 & 82.1 & 7.1 \\
\hline Sangiampong et al. (2006) & Radiography & 3.2 & 93.5 & 3.2 \\
\hline Natsis et al. (2007) & Visual Inspection & 12.1 & 56.5 & 28.8 \\
\hline Paraskevas et al. (2008) & Visual Inspection & 26.1 & 55.6 & 18.1 \\
\hline Collipal et al. (2009) & Visual Inspection & 8.0 & 50.0 & 42.0 \\
\hline
\end{tabular}


COLLIPAL, E.; SILVA, H.; ORTEGA, L.; ESPINOZA, E. \& MARTÍNEZ, C. El acromion y sus diferentes formas. Int. J. Morphol., 28(4):1173-1180, 2010.

La morfología del acromion, sus relaciones con el proceso coracoides y tubérculo supraglenoídeo es importante en la determinación de la dimensión del espacio subacromial, considerando que las variaciones de estas estructuras pueden provocar patologías como el síndrome del pinzamiento del espacio subacromial. Para aportar información de las diferentes dimensiones y forma del acromion, hemos estudiado en 36 escápulas del museo de la Unidad de Anatomía, Universidad de La Frontera, los siguientes parámetros: longitud, espesor, ancho, proyección anterior, distancia acromiocoracoidea y acromio supraglenoídea. De acuerdo a su forma se clasificaron en acromion tipo I (plano), tipo II (curvo), tipo III (ganchoso). Los promedios de las variables longitud, proyección anterior, fueron estadísticamente significativas en el acromion del lado derecho. En relación a su clasificación, el 8\% fue de tipo I, 50\% tipo II, 42\% tipo III. Los datos anatómicos obtenidos permitirán a los profesionales de la salud contar con nuevos antecedentes morfométricos del acromion pudiendo servir de base para futuros estudios de patologías del miembro superior.

PALABRAS CLAVE: Acromion; Morfometría; Anatomía.

\section{REFERENCES}

Arenas, P. J. A.; Ortega, A. J.A.; Arenas, M. A.; Ayala, P. H \& Garbayo, M. A. J. Síndrome subacromial con ruptura del manguito de los rotadores. Tratamiento y pronóstico. Rev. Esp. de Cir. Ost., 40:159-69, 2005.

Bigliani, L. U.; Morrison, D. S \& April, E. W. The morphology of the acromion and its relationship to rotator cuff tears. Orthop. Trans., 10:228, 1986.

Getz, J. D.; Recht, M. P.; Piraino, D. W.; Schils, J. P.; Latimer, B. M.; Jellema, L. M. \& Obuchowski, N. A. Acromial Morphology: Relation to Sex, Age, Symmetry, and Subacromila Enthesophytes. Radiology, 199:737-42, 1996.

Epstein, R. E.; Schweistzer, M. E.; Frieman, B. G.; Fenlin, J. M. JR. \& Mitchell, D. G. Hooked Acromion: Prevalence on MR Images of Painful Shoulders. Radiology, 187:479-81, 1993.

Ikemoto, R. Y.; Becerra, A. D.; Monte, F. A.; Telles, R. B.; Fujiki, E. N. \& Porto, L. C. Acrômio em forma de gancho: uma variação anatômica ou um processo degenerativo?. Rev. Bras. Ortop., 40:454-63, 2005.

Natsis, K.; Tsikaras, P.; Totlis, T.; Gigis, I.; Skandalakis, P.; Appell, H. J. \& Koebke, J. Correlation between the four types of acromion and the existence of enthesophytes: a study on 423 dried scapulas and review of the literature. Clin. Anat., 20:267-72, 2007.

Neer, C. S. 2nd. Anterior acromioplasty for the chronic impingement syndrome in the shoulder: a preliminary report. J. Bone Joint Surg. Am., 54:41-50, 1972.

Nicholson, G. P.; Goodman, D. A.; Flatow, E. L. \& Bigliani, L. U. The acromion: morphologic condition and agerelated changes. A study of 420 scapulas. J. Shoulder Elbow Surg., 5:1-11, 1996.

Oda, J. Y.; Luzetti, D. A. \& Bertolini, S. M. M. G. Estudo Morfométrico de Acrômios em Humanos. Arq. Ciênc. Saúde Unipar, 4:207-13, 2000.

Paraskevas, G.; Tzaveas, A.; Papaziogas, B.; Kitsoulis, P.; Natsis, K. \& Spanidou, S. Morphological parameters of the acromion. Folia Morphol., 67:255-60, 2008.

Shah, N. N.; Bayliss, N. C. \& Malcolm, A. Shape of the acromion: congenital or acquired--a macroscopic, radiographic, and microscopic study of acromion. $J$. Shoulder Elbow Surg., 10:309-16, 2001.

Schippinger, G.; Bailey, D.; McNally, E. G.; Kiss, J. \& Carr, A. J. Anatomy of the normal acromion investigated using MRI. Langenbecks Arch. Chir., 382:141-4, 1997.

Testut, L. \& Latarjet, A. Tratado de Anatomía Humana. $9^{\text {ed }}$. Barcelona, Salvat, 1971.

Wang, J. C.; Hatch, J. D. \& Shapiro, M. S. Comparison of MRI and radiographs in the evaluation of acromial morphology. Orthopedics, 23:1269-71, 2000.

\section{Correspondence to: \\ Prof. Erika Collipal Larré \\ Facultad de Medicina \\ Universidad de La Frontera \\ Casilla 54-D \\ Temuco \\ CHILE}

Email: ecollipa@ufro.cl
Received : 17-06-2010

Accepted : 18-07-2010 